\title{
Extracorporeal Photopheresis in Graft-versus-Host Disease
}

\author{
Beatrice Drexler ${ }^{a, b}$ Andreas Buser ${ }^{a, b}$ Laura Infanti ${ }^{a, b} \quad$ Gregor Stehle ${ }^{a, b}$ \\ Joerg Halter ${ }^{a}$ Andreas Holbro ${ }^{a, b}$ \\ ${ }^{a}$ Division of Hematology, University Hospital Basel, Basel, Switzerland; 'b Blood Transfusion Center, Swiss Red Cross, \\ Basel, Switzerland
}

\section{Keywords}

Extracorporeal photopheresis · Graft-versus-host disease · Treatment

\begin{abstract}
Background and Summary: Extracorporeal photopheresis $(E C P)$ is a leukapheresis-based procedure used in the therapy of acute and chronic graft-versus-host disease (aGvHD, cGvHD) and other diseases. Based on the substantial efficacy and the excellent safety profile in the absence of immunosuppression ECP has established itself as a major treatment form for steroid-refractory GvHD. Here we review the current literature on ECP as a treatment option for patients with aGvHD as well as cGvHD. Key Messages: ECP is a well-established second-line therapy for CGvHD. Its role in the treatment of aGvHD is less clear but also points towards an effective second-line therapy option. In the future ECP could play a role in the prevention of GvHD. More experimental and randomized controlled trials are needed to define the best patient selection criteria, settings, and therapy regimens for GvHD.

(c) 2020 S. Karger AG, Basel
\end{abstract}

\section{Introduction}

Extracorporeal photopheresis (ECP) is a leukapheresis-based procedure used for the treatment of graft-versus-host disease (GvHD). Despite improvements in phar- macologic prevention and therapy as well as in graft manipulation technologies, GvHD continues to be a major source of disabling morbidity and mortality after allogeneic hematopoietic stem cell transplantation (HSCT) [1, 2]. GvHD is an immune-mediated, potentially life-threatening syndrome in which host tissues are attacked by donor immune cells $[1,2]$. The disease is classified as acute or chronic GvHD (aGvHD, cGvHD) on the basis of different manifestations and at least in part also pathophysiologic mechanisms. Corticosteroids remain the established standard first-line treatment for GVHD, but only up to $50-60 \%$ of patients respond to this therapy and the majority of patients require additional salvage and/or second-line therapy $[1,2]$. Multiple second-line treatments have been explored, but they are often not able to control GvHD activity and harbor several side effects, most importantly profound systemic immunosuppression with an increased risk of infection, disease relapse, or unacceptable late effects. Based on the substantial efficacy and the excellent safety profile in the absence of severe systemic immunosuppression, ECP has established itself as a major treatment form for steroid-refractory GvHD.

Here we review the current literature on ECP as a treatment option for patients with aGvHD as well as cGvHD.

\section{History}

The idea of ECP originates from the so called "PUVA" therapy, in which psoralen is taken orally to sensitize the skin and thereafter the skin is exposed to UVA light. The 
Table 1. Comparison between in-line and off-line methods

\begin{tabular}{lll}
\hline & Closed system (in-line method) & Open system (off-line method) \\
\hline Manufacturer & $\begin{array}{l}\text { CELLEX (Therakos) } \\
\text { UVAR XTS (Therakos) } \\
\text { AMICUS ECP System using a Phelix irradiation device } \\
\text { (Fresenius Kabi) }\end{array}$ & $\begin{array}{l}\text { Spectra Optia (Terumo BCT) } \\
\text { AMICUS or COM.TEC (Fresenius Kabi) } \\
\text { together with a UVA irradiator }\end{array}$ \\
\hline Principle & $\begin{array}{l}\text { Integrated device on a single instrument, all components } \\
\text { have been validated together }\end{array}$ & $\begin{array}{l}\text { Separate devices for each step, have not been } \\
\text { validated together }\end{array}$ \\
\hline Cell separator technology & Continuous or discontinuous & Continuous \\
\hline Venous access & Single or double & Double \\
\hline Anticoagulant & Heparin or citrate & Citrate \\
\hline Quality control of cells & No & Yes \\
\hline Duration & $1.5-2 \mathrm{~h}$ & $3-4 \mathrm{~h}$ \\
\hline Weight limit & Yes, red blood cell prime needed if $>115 \%$ extracorporeal volume & No \\
\hline
\end{tabular}

historical basis of this principle dates back to ancient Egypt, where people with vitiligo ingested a plant (Ammi majus) found on the banks of the Nile river, bathed in the sun, and noticed a recovery in melanin production. Nowadays, PUVA is used in the treatment of a variety of mainly dermatologic diseases, including psoriasis and neurodermitis [3].

The first clinical application of ECP was for the treatment of Sezary syndrome, the leukemic form of cutaneous T-cell lymphoma (CTCL). Edelson et al. [4] developed ECP from therapeutic leukapheresis as a "PUVA-therapy for lymphoma cells." After their landmark study in 1987 [4] ECP received approval by the US Food and Drug Administration (FDA) in 1988. The next clinical application of ECP was for the treatment of systemic scleroderma, lupus erythematosus, rheumatoid arthritis, and other autoimmune diseases [5-7]. Chronic GvHD as a main disease entity for ECP was studied and first reported in 1994 [8]. Since then, ECP has been studied extensively in GvHD.

\section{Techniques and Systems}

ECP involves the following steps: (1) leukapheresis, (2) photoactivation with 8-methoxypsoralen (8-MOP)/ultraviolet-A (UVA), and (3) reinfusion $[9,10]$.

For separation of mononuclear cells (MNC) from plasma and nonnucleated cells, whole blood is collected via a peripheral vein or permanently implanted catheter. The collected MNC are then exposed to UVA irradiation in the presence of the photosensitizing agent 8-MOP prior to reinfusion into the patient. Two different methods are established for this procedure (Table 1): the "closed system" (also called the in-line method) and the so called "open system" (also known as the off-line method). The closed system is a "1-step method" in which cell-separa- tion, 8-MOP infusion, photoactivation, and reinfusion into the patient are fully integrated in one dedicated ECP device. The open system is a "2-step process" in which $\mathrm{MNC}$ are first collected by a separate routine apheresis device, whereafter the MNC concentrate is transferred to a second device for UVA irradiation (such as MacoGenic ${ }^{\circledR}$ by Maco Pharma or the UV-A PIT System ${ }^{\circledR}$ by PIT Medical Systems $\mathrm{GmbH}$ ) and subsequent reinfusion.

Regulatory approval of the different systems varies depending on the respective health agency and country. The closed systems (i.e., Therakos ${ }^{\circledR}$ CELLEX), including their kits and applied drugs (i.e., UVADEX ${ }^{\mathrm{TM}}$ ), are moreover approved for ECP in many countries. The open systems on the other hand can be operated with a combination of different devices, which have not been validated for use together. Although these devices may be European $\mathrm{CE}$ marked or have FDA approval on their own, they are not specifically approved for combined application in photopheresis.

Closed systems rely on heparin for anticoagulation, which can be contraindicated in heparin-induced thrombocytopenia as well challenging due to its longer half-life in patients with a high bleeding risk (such as patients with a low-platelet count and systemic anticoagulation) and active bleeding. In this setting the use of ACD-A is preferable due to its shorter half-life, which is the standard anticoagulant for the open systems. Some selected centers also have gathered experience with the use of ACD-A in the closed system Therakos Cellex ${ }^{\circledR}$; however, this application remains off-label at the moment. The mean duration per procedure is about $1-2 \mathrm{~h}$, depending on the system used and according to the aimed target cell number.

In low-weight patients (children), red blood cell priming is necessary for both systems (i.e., in the Therakos 


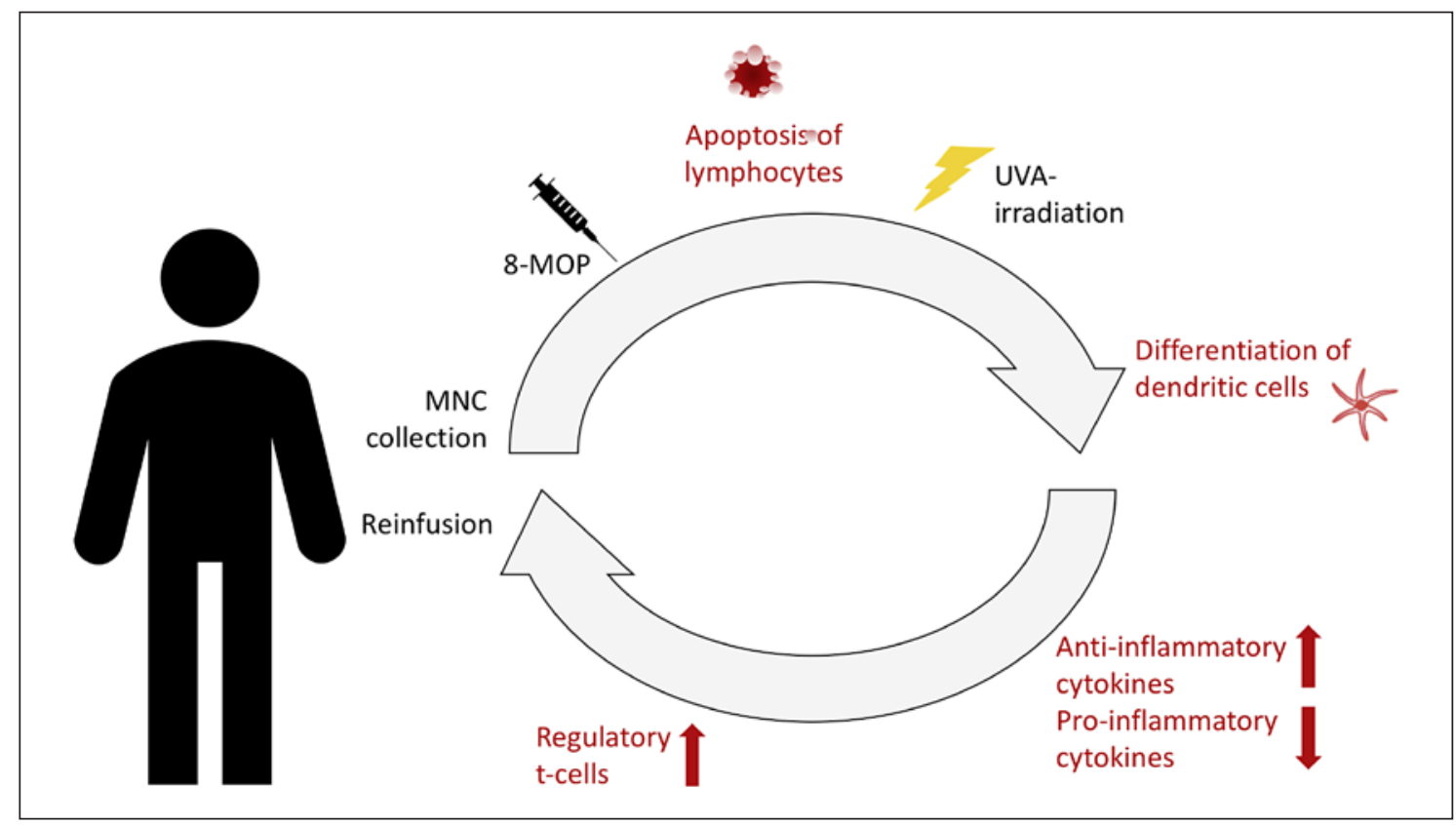

Fig. 1. Procedure and mode of action. Stages of the procedure and the hypothesis for the mode of action. (1) MNC are separated from peripheral blood (buffy coat) and concentrated before ex vivo incubation with 8-MOP and photoactivation by UVA-irradiation. (2) ECP-treated lymphocytes undergo apoptosis. (3) Differentiation of immature dendritic cells are triggered by contact of these cells with extracorporeal surfaces. (4) Recognition of apoptotic cells induces an anti-inflammatory response with a lower production of proinflammatory cytokines and a higher production of anti-inflammatory cytokines. (5) Antigen-presenting cells promote generation of regulatory T cells. (6) Reinfusion of irradiated cells into the patient.

Cellex ${ }^{\circledR}$ device in patients weighing $<40 \mathrm{~kg}$, and in the Spectra Optia ${ }^{\circledR}$ in patients weighing $<25 \mathrm{~kg}$ ). As an alternative, "mini photopheresis," which only processes 100 $200 \mathrm{~mL}$ of whole blood and is well tolerated, can be an option in low-weight patients [11].

Overall, both systems have proven their efficacy and are used widely in routine clinical practice, but studies for a direct head-to-head comparison will likely not be performed. Each center has to balance the benefits versus the drawbacks of each particular system, i.e., for centers with small patient numbers the open system can allow more apheresis procedures when using the apheresis device (i.e., Spectra Optia ${ }^{\circledR}$; Terumo BCT) not only for ECP but also for other indications. On the other hand, the handling of the closed system is less demanding, it is associated with a lower risk of improper reinfusion (risk of infection), and it has fewer regulatory boundaries.

\section{Mechanism of Action}

Although the first study on ECP was completed 35 years ago and since then over 2 million of treatments have been performed, the mechanism of action is still incompletely understood.

Several mechanisms have been suggested that modulate the in vivo immune response. These seem to differ between the different disease entities and currently are thought to revolve mainly around the apoptosis of lymphocytes and differentiation of dendritic cells (Fig. 1).

The first studies postulated that ECP initiates apoptosis in lymphoid cells as a result of 8-MOP binding covalently to DNA, leading to cell cycle arrest $[12,13]$.

Further studies investigated intensively the increased differentiation of immature dendritic cells [14], which is triggered by contact of these cells with extracorporeal surfaces in the tubing and radiation chamber of the ECP device and with platelets [15]. Dendritic cells are the master switches governing antigen-specific T-cell immunity and $\mathrm{T}$-cell tolerance, and thereby they are central and critical components of the ECP immunotherapeutic response. In fact, experts have judged ECP as a dendritic antigen-presenting cell-based therapy [16].

The cytokine profile in the peripheral blood is modified after reinfusion of 8-MOP and UVA-treated cells [17], showing a switch from proinflammatory to anti-inflammatory cytokine production.

During ECP T-cells are also activated, leading to generation of regulatory T-cells which play a pivotal role in the downregulation of immune reactions. In aGvHD patients in particular, a significantly higher number of regulatory $\mathrm{T}$ cells is detectable in peripheral blood after ECP [18]. Gatza et al. [19] also showed that injection of ECP-treated splenocytes from mice developing GvHD triggers IL-10-produc- 
Table 2. Category and grade recommendations for ECP according to the ASFA guidelines of 2019 [10]

\begin{tabular}{lll}
\hline Indication & Category & Grade \\
\hline Transplant setting & & \\
HSCT & & II \\
$\quad$ aGvHD & II & 1B \\
$\quad$ cGvHD & II & 1C \\
Lung transplant & & \\
$\quad$ Bronchiolitis obliterans syndrome & II & 2A \\
Cardiac transplant & II & 1B \\
$\quad$ Rejection prophylaxis & & \\
$\quad$ Cellular rejection & III & 2C \\
Liver transplant & III & 2B \\
$\quad$ Densitization (ABOi) & & \\
$\quad$ Acute rejection/immune suppression withdrawal & & 1B \\
\hline Dermatology & I & 2C \\
Cutaneous T-cell lymphoma & III \\
$\quad$ Erythrodermic & III & 2A \\
$\quad$ Nonerythrodermic & III & 2C \\
Ptopic dermatitis & III & 2B \\
Psoriasis, disseminated pustular & & \\
\hline Other & III & III \\
Skleroderma & III \\
Nephrogenic systemic fibrosis & & 2C \\
Crohn's disease & 2C \\
\hline
\end{tabular}

ing regulatory $\mathrm{T}$ cells, which are able to reverse experimental GvHD [19]. Altogether, the current data suggests that ECP might be able to trigger an immune tolerance.

However, the generation of regulatory $\mathrm{T}$ cells does not explain how ECP selectively targets pathogenetic $\mathrm{T}$ cells in the setting of CTLC [20]. In this setting it has been rather suggested that ECP induces an antitumor response directed toward tumoral $\mathrm{T}$ cells [21].

Overall, the full concept and mode of action of ECP remain unclear and a deeper understanding of the mechanism of action would help to optimize treatment regimens.

\section{Results}

\section{Established Indications}

ECP has been established in several indications that are listed by the latest American Society for Apheresis (ASFA) guidelines based on a stringent review of up-todate literature, an analysis of the quality of evidence, and the strength of recommendations from this evidence ( $\mathrm{Ta}$ ble 2) [10]. Further recommendations were made recently by the section "Preparative and Therapeutic Hemapheresis" of the German Society for Transfusion Medicine and Immunohematology [22]. While the best evidence of ECP effectiveness exists for from the treatment of CTCL, in the following section we will focus on the available evidence for the use in GvHD.

\section{General use of ECP for GvHD}

$\mathrm{ECP}$ is used in 2 clinical settings for HSCT patients, i.e., prevention and treatment of GvHD. Although ECP is a widely recognized treatment modality for GvHD, the published data is limited to nonrandomized trials and case reports/series. Only 2 randomized clinical trials have evaluated the efficacy of ECP in cGvHD. The limited data and the heterogeneity of the patients and stem cell sources, combined with significant differences among practices between centers, pose a challenge in the evaluation of the currently available literature on the efficacy of ECP in GvHD. Furthermore, grading of GVHD has evolved in recent years and assessment of the disease itself remains challenging $[23,24]$. Nonetheless, several expert groups have published consensus recommendations on treatment indications, regimens, and response assessments in patients undergoing ECP for GvHD [9, 10, 25, 26] (Table 3). These recommendations are similar and have not been prospectively studied in a head-to-head comparison. They are mainly based on expert opinion (i.e., survey in transplant centers) [27], experiences from other indications (i.e., CTLC), the frequency and interval of ECP often depending on the patient's follow-ups, the logistics and capacity of the apheresis unit, personnel, and reimbursement.

\section{Prevention of GvHD}

The preventive role of ECP for GvHD has only been tested in a handful of studies, either in the application of 
Table 3. Expert recommendations on treatment indications and regimens

\begin{tabular}{|c|c|c|}
\hline Group & aGvHD & cGvHD \\
\hline ASFA [10] & $\begin{array}{l}\text { Indication: salvage treatment after failure of first-line } \\
\text { therapy } \\
\text { Regimen: } 1 \text { cycle ( } 2 \text { treatments typically on } 2 \\
\text { consecutive days) performed weekly until disease } \\
\text { response and then tapered to every other week before } \\
\text { discontinuation }\end{array}$ & $\begin{array}{l}\text { Indication: steroid-refractory or steroid-dependent } \\
\text { extensive cGvHD } \\
\text { Regimen: } 1 \text { cycle weekly for } 4 \text { weeks (or consider biweekly if } \\
\text { treating only mucocutaneous cGVHD) and then } 1 \text { cycle } \\
\text { every } 2 \text { weeks or for at least } 8 \text { weeks (assess at } 2-3 \text { monthly } \\
\text { intervals), continue to maximum response every } 2-4 \text { weeks } \\
\text { with tapering }\end{array}$ \\
\hline $\begin{array}{l}\text { German Working Group on Bone } \\
\text { Marrow and Blood Stem-Cell } \\
\text { Transplantation }[42,43]\end{array}$ & $\begin{array}{l}\text { Indication: second-line treatment } \\
\text { Regimen: initially } 3 \times / \text { week, then } 2 \times / \text { week until } \\
\text { resolution }\end{array}$ & $\begin{array}{l}\text { Indication: salvage therapy after first-line therapy } \\
\text { Regimen: - }\end{array}$ \\
\hline European Dermatology Forum [9] & $\begin{array}{l}\text { Indication: no response to first-line therapy with } \\
\text { corticosteroids at } 2 \mathrm{mg} / \mathrm{kg} / \mathrm{day} \text {, defined as } \\
\text { progression of aGvHD after } \geq 3 \text { days of corticosteroid } \\
\text { treatment or lack of response after } \geq 7 \text { days of } \\
\text { corticosteroids } \\
\text { Regimen: } 2-3 \text { treatments per week with cessation } \\
\text { upon achievement of a complete response }\end{array}$ & $\begin{array}{l}\text { Indication: second-line treatment for steroid-refractory } \\
\text { patients (progression on prednisone at } 1 \mathrm{mg} / \mathrm{kg} / \text { day for } 2 \\
\text { weeks, stable disease on at least } 0.5 \mathrm{mg} / \mathrm{kg} / \mathrm{day} \text { for } 4-8 \\
\text { weeks and inability to taper steroids below } 0.5 \mathrm{mg} / \mathrm{kg} / \text { day) } \\
\text { Regimen: } 1-2 \text { cycle(s) of ECP every } 1-2 \text { weeks for } 3 \text { months; } \\
\text { thereafter, intervals can be increased depending on the type } \\
\text { of lesions, extension, and the clinical response; if cGvHD } \\
\text { progress consider a change in the treatment strategy }\end{array}$ \\
\hline $\begin{array}{l}\text { United Kingdom Photopheresis } \\
\text { Society [25] }\end{array}$ & $\begin{array}{l}\text { Indication: no response to first-line therapy with } \\
\text { corticosteroids at } 2 \mathrm{mg} / \mathrm{kg} / \mathrm{day} \text {, defined as } \\
\text { progression of aGvHD after } \geq 3 \text { days of corticosteroid } \\
\text { treatment or lack of response after } \geq 7 \text { days of } \\
\text { corticosteroids } \\
\text { Regimen: } 2-3 \text { treatments per week with cessation } \\
\text { upon achievement of a complete response }\end{array}$ & $\begin{array}{l}\text { Indication: second-line treatment in skin, oral or liver } \\
\text { cGvHD, third-line treatment for other organs } \\
\text { Regimen: } 2 \text { consecutive days every week with minimum } \\
\text { assessment after } 3 \text { months }\end{array}$ \\
\hline BCSH/BSBMT $[26,44]$ & $\begin{array}{l}\text { Indication: second-line treatment of aGvHD grade } \\
\text { III/IV } \\
\text { Regimen: optimal schedule and duration not defined }\end{array}$ & $\begin{array}{l}\text { Indication: second-line treatment in skin, oral, and liver } \\
\text { cGvHD, may also be considered as third-line treatment for } \\
\text { cGvHD involving other organs } \\
\text { Regimen: fortnightly-paired treatments for a minimum } \\
\text { assessment period of } 3 \text { months }\end{array}$ \\
\hline
\end{tabular}

ECP within the conditioning regimen or as GvHD prophylaxis after HSCT.

The first investigations were performed by Miller et al. [28] in 2004 by integrating ECP in a reduced-intensity conditioning (RIC) regimen together with pentostatin and low-dose body irradiation (600 cGy). Nine percent of the patients developed aGvHD higher than grade 2, while $43 \%$ of the patients developed cGvHD, with $12 \%$ showing extensive disease. The study population was heavily pretreated and many cofactors (concomitant conditioning agents, GvHD prophylaxis, donor, and bone marrow source) possibly influenced GvHD rates, thus making it difficult to draw further conclusions from this study.

Shaughnessy et al. [29] applied ECP before initiating a myeloablative conditioning regimen consisting of cyclophosphamide and fractionated total-body irradiation (10-13.5 Gy) [29]. They hypothesized that the use of ECP 4 days before the beginning of myeloablative conditioning could modulate the host antigen-presenting cell function, thereby reducing the incidence of GvHD. They matched their outcomes to historical controls with similar conditioning regimens and GvHD prophylaxis with- out ECP, thereby showing that the addition of ECP resulted in a significantly lower risk of aGvHD grades 2-4.

In a further study on GvHD prophylaxis, ECP was tested together with Etanercept administered twice weekly for 8 weeks [30]. ECP was performed weekly from day +28 post-HSCT to approximately day +70 , followed by every other week up to day +100 and thereafter monthly to day +180 . Further GvHD prophylaxis consisted of tacrolimus and mycophenolate mofetil. The results showed that aGvHD developed in $57 \%$ of the patients and there was a high incidence of steroid-dependent $\mathrm{cGvHD}$ once the prophylaxis was stopped, showing that this strategy was not effective.

Recently, Michallet et al. [31] performed a prospective multicenter phase 2 trial for prophylactic ECP after reduced-intensity conditioning. ECP took place twice per week during the first 2 weeks and then once a week for the next 4 weeks for a total of 8 ECP courses. The cumulative incidence was $15 \%$ for aGvHD and $22 \%$ for cGvHD, pointing towards encouraging results.

Experimentally, preliminary data also indicates that ECP could have a role in processing of donor leukocytes pretransplant. In a murine model, the exposure of tissue 
Table 4. Results of second-line treatment of aGvHD with ECP

\begin{tabular}{|c|c|c|c|c|c|c|}
\hline Study & Patients, $n$ & $\begin{array}{l}\text { CR skin, } \\
n(\%)\end{array}$ & $\begin{array}{l}\text { CR liver, } \\
n(\%)\end{array}$ & $\begin{array}{l}\text { CR gut, } \\
n(\%)\end{array}$ & $\begin{array}{l}\text { ORR, } \\
n(\%)\end{array}$ & OS, \% \\
\hline Greinix et al. [46] & 21 & $12 / 20(60)$ & $8 / 12(67)$ & $0 / 4(0)$ & & 57 at 25 months \\
\hline Salvaneschi et al. [47] & 9 & $6 / 9(67)$ & $1 / 3(33)$ & $3 / 5(60)$ & & 67 \\
\hline Dall'Amico and Messina [48] & 14 & $10 / 14(71)$ & $4 / 7(57)$ & $6 / 10(60)$ & & 57 \\
\hline Messina et al. [49] & 33 & $25 / 33(76)$ & $9 / 15(60)$ & $15 / 20(75)$ & & 69 at 5 years \\
\hline Greinix et al. $[50,51]$ & 59 & $47 / 57(82)$ & $14 / 23(61)$ & $9 / 15(60)$ & & 47 at 5 years \\
\hline Garban et al. [52] & 12 & $8 / 12(67)$ & $0 / 2(0)$ & $2 / 5(40)$ & & 42 \\
\hline Kanold et al. [53] & 12 & $9 / 10(90)$ & $5 / 9(55.5)$ & $5 / 6(83)$ & & 75 at 8.5 months \\
\hline Calore et al. [54] & 15 & $12 / 13(92)$ & $14 / 14(100)$ & & & 85 at 5 years \\
\hline Perfetti et al. [55] & 23 & $15 / 23(65)$ & $3 / 11(27)$ & $8 / 20(40)$ & & 48 at 37 months \\
\hline González-Vicent et al. [56] & 8 & $8 / 8(100)$ & $2 / 2(100)$ & $4 / 7(57)$ & & 37.5 \\
\hline Perotti et al. [57] & 50 & $39 / 47(83)$ & $16 / 24(67)$ & $8 / 11(73)$ & & 64 at 1 years \\
\hline Malagola et al. [58] & 45 & & $41 / 45(91 \%)$ & & & \\
\hline Niittyvuopio et al. [59] & 52 & $24(77)$ & $1(33)$ & $14(34)$ & $32(62)$ & - \\
\hline Cid et al. [60] & 21 & & & & $12(57)$ & 38 \\
\hline
\end{tabular}

Values are based on previous reviews $[9,45]$ integrated with current data. CR, complete response; ORR, overall response rate; OS, overall survival.

donor leukocytes to UVA-activated 8-MOP and their infusion into HLA-mismatched tissue recipients enhanced tolerance to transplanted heart, liver, and kidney [16]. This is a novel approach since ECP is conventionally performed after HSCT processing of donor cells. However, open issues remain a potential effect on relapse rate in malignant diseases. Further clinical trials are needed to confirm this otherwise elegant strategy, but it could prove to be an elegant prevention strategy for inducing tolerance in the transplant setting.

Overall, ECP for the prevention of GvHD has not found its way into routine use and the effect remains to be further validated in future studies.

\section{Treatment of $a G v H D$}

While corticosteroids remain the backbone of firstline treatment of aGvHD, options for second-line therapy vary, with no clear advantage of one over the other. Furthermore, very little prospective controlled trial data is available to date. The choice of second-line therapy is not standardized, often relies on center-specific experiences, may be partly reimbursement driven, and can differ even within a center depending on an individual physician's preference. The lacking standard definition of refractory aGvHD further complicates the decision and research process. The role of ECP for second-line therapy in aGvHD is less well supported by published data in comparison to $\mathrm{cGvHD}$, but several reports have prompted its increased use (summarized in Table 4).

Considering that response assessment was not uniform across studies the interpretation of the results is limited. Overall response rates for steroid-refractory aGvHD range from 52 to $100 \%$, with responses in $66-100 \%$ for skin, $40-83 \%$ for the gastrointestinal tract, and $27-71 \%$ for liver aGvHD. A multicenter comparative analysis of ECP $(n=57)$ versus anticytokine therapy with inolimumab or etanercept $(n=41)$ as a second-line treatment for steroid refractory aGvHD reported a higher overall response in the ECP group ( 66 vs. $32 \% ; p=0.001$ ), along with a significant survival advantage for patients receiving ECP [32].

Overall, the results for ECP are not superior to results reported for alternative salvage therapies for steroid refractory aGvHD. However, as discussed before, the profile of adverse effects, steroid sparing, and organ specific responses need to be included in decision making and efficacy assessment.

\section{Treatment of $c G v H D$}

As in aGvHD, corticosteroids are the standard of care for first-line treatment of $\mathrm{cGvHD}$, whereas the standard for the optimal second-line treatment is not clearly defined. Compared to aGvHD, in cGVHD ECP has been studied more extensively with variable responses, although the majority of data relies on uncontrolled trials or retrospective studies. There are 3 prospective trials [33-35] and 1 recently published prospective randomized study on ECP in cGvHD based on NIH 2015 consensus criteria [32]. Hence, several expert groups have reached out to the consensus that ECP has an established place as second-line or adjuvant therapy in cGvHD.

Looking at the published data so far, the only randomized controlled trial that investigated the efficacy of ECP in patients with steroid-refractory $\mathrm{cGvHD}$ reported no statistically significant difference in total skin scores at 12 weeks of ECP in combination with salvage therapy versus salvage therapy alone [34]. However, patients in the ECP group showed a $40 \%$ complete and partial response com- 
Table 5. Results of second-line treatment of cGvHD with ECP

\begin{tabular}{|c|c|c|c|c|c|c|c|}
\hline Author & Patients, $n$ & $\begin{array}{l}\mathrm{CR} / \mathrm{PR} \\
\text { skin, \% }\end{array}$ & $\begin{array}{l}\text { CR/PR } \\
\text { liver, \% }\end{array}$ & $\begin{array}{l}\mathrm{CR} / \mathrm{PR} \\
\text { oral, } \%\end{array}$ & $\begin{array}{l}\text { ORR, } \\
\%\end{array}$ & $\begin{array}{l}\text { Cortico- } \\
\text { steroid sparing }\end{array}$ & OS \\
\hline Greinix et al. [61] & 15 & 100 & 90 & 100 & 93 & Yes & $14 / 15(93)$ \\
\hline Salvaneschi et al. [47] & 14 & 83 & 67 & 67 & 64 & Yes & $11 / 14(79)$ \\
\hline Seaton et al. [62] & 28 & 48 & 32 & 21 & 36 & No & $24 / 28(86)$ \\
\hline Apisarnthanarax et al. [63] & 32 & 59 & NA & NA & 56 & Yes & $19 / 32(59)$ \\
\hline Foss et al. [33] & 25 & 64 & 0 & 46 & 64 & Yes & $15 / 25(60)$ \\
\hline Rubegni et al. [64] & 32 & 81 & 77 & 92 & 69 & NA & NA \\
\hline Greinix [65] & 47 & 93 & 84 & 95 & 83 & Yes & $42 / 47(89)$ \\
\hline Couriel et al. [66] & 71 & 57 & 71 & 78 & 61 & Yes & $13 / 71(18)$ \\
\hline Kanold et al. [53] & 15 & 75 & 82 & 86 & 73 & No & $10 / 15(67)$ \\
\hline Perseghin et al. [67] & 25 & 80 & 67 & 78 & 80 & NA & $19 / 25(76)$ \\
\hline Flowers et al. [34] & 48 & 40 & 29 & 53 & & Yes & 47/48 (98) \\
\hline Dignan et al. [68] & 69 & 92 & NA & 91 & 79 & Yes & $50 / 69(72)$ \\
\hline Greinix et al. [35] & 29 & 31 & 50 & 70 & 31 & Yes & $29 / 29(100)$ \\
\hline Del Fante et al. [69] & 88 & NA & NA & NA & NA & NA & NA \\
\hline Hautmann et al. [70] & 32 & 59 & 100 & 60 & 44 & No & $21 / 32(66)$ \\
\hline \multicolumn{8}{|c|}{$\begin{array}{l}15 / 45(33) \\
\text { CR for all manifestations }\end{array}$} \\
\hline Cid et al. [60] & 26 & & & & 77 & & 61 \\
\hline
\end{tabular}

Values are based on previous reviews $[9,45]$ and current data. Numbers in parentheses are percents. CR, complete response; PR, partial response; ORR, overall response rate; OS, overall survival; NA, not available.

pared to $10 \%$ in the non-ECP group. As a further advantage, corticosteroids could be tapered more rapidly in the ECP group.

A cross-over study after 24 weeks of ECP showed responses of 33\% in skin and up to $70 \%$ in extracutaneous tissues, emphasizing the importance of prolonged ECP for an optimal therapeutic effect [35].

A systematic review showed pooled response rates for skin, liver, ocular, oral, lung, gut, and musculoskeletal steroid refractory cGvHD of $74,68,60,72,48,53$, and $64 \%$, respectively [36].

Most recently, the first randomized controlled trial was published in the first-line setting for moderate to severe cGvHD [32], reporting results after 28 weeks of ECP treatment together with standard of care (corticosteroids) versus standard of care alone. There were no significant differences in the overall response rates between the groups ( $74 \%$ in the ECP group vs. $60.9 \%$ in the standardalone group, by blinded assessors), but a trend of improvement of quality of life in the ECP group was observed. Further clinical studies are needed to understand the role of ECP in the first-line setting.

Numerous small studies have been published to address the role of ECP in $\mathrm{cGvHD}$, showing varying disease responses. Table 5 summarizes the studies on the effect of ECP in second-line treatment of cGvHD, though response assessment was also not uniform across all studies.

Current consensus recommendations point out that treatment should be performed on 2 consecutive days ev- ery week or every 2 weeks for at least 8-12 weeks or until a response is noticeable (Table 3). The most recent study by Cid et al. [32] showed that their center-specific off-line ECP schedule was also efficacious, with overall response rates of $57 \%$ for aGvHD and $38 \%$ for cGvHD. The authors treated patients with aGVHD twice a week for the first 2 weeks, followed by once a week for 2 more weeks. After the first month of treatment, the patients received treatment once every 2 weeks for a minimum total of 16 ECP procedures. Patients with chronic GVHD were treated once a week for 4 weeks followed by once every 2 weeks for a minimum total of 14 ECP procedures. This data highlights that the optimal treatment schedule is still not clear, and most likely several regimens have to be tested ideally in a head-to-head comparison.

\section{Safety and Quality Management}

ECP therapy is characterized by an excellent safety profile, with almost no serious adverse events reported so far as long as patients are carefully selected [37]. The main side effects are mild and comprise the increased photosensitivity from 8-MOP and patient-related issues due to repeated venous puncture and volume shifts during the procedure. There are no reports of an increased infection risk or disease relapse, although a warning has been issued for splenectomized patients.

Due to increased photosensitivity, patients are instructed to wear eye and skin protection for $24 \mathrm{~h}$ after ECP treatment and ECP should not be performed in pa- 
tients with aphakia due to an increased risk of retinal damage [38].

ECP relies on either repeating peripheral venous puncture or long-term venous access (peripheral or central), which can result in local hematoma, arterial puncture, phlebitis, venous thromboembolism, catheter-related infection, and pneumothorax.

With the closed Cellex ${ }^{\circledR}$ system in particular, venous thromboembolism has been reported, as noted in a 2018 MedWatch Safety Alert issued by the FDA [39]. These events are, to date, not fully understood; nonetheless, physicians should inform their patients on the potential risk during ECP treatment.

Other side effects observed during ECP are primarily related to volume shifts since hypotension may occur during any treatment involving extracorporeal circulation. This is of major importance for low-weight patients including pediatric patients, since priming of the machine may be necessary.

Absolute contraindications for ECP exist for patients who cannot tolerate methoxsalen, show hemodynamic instability, have an uncontrolled systemic infection, and are affected by coagulation disorders with a high bleeding risk.

ECP centers should be quality assured. ECP requires well-maintained and validated machines, specifically trained staff, and a quality management system to ensure that the clinical standards for safe, high-quality procedures are achieved and maintained. A quality control of the collected cells is recommended (i.e., cell count and cell type) and can be collected not only by users of the open system but also by users of the closed system [40].

\section{Special Challenges in HSCT Patients}

Patients affected by cutaneous GvHD often show sensitive und vulnerable skin features, and thus multiple insertions of peripheral intravenous catheters - as are needed for long-term ECP - can be cumbersome. In addition, peripheral vein access can be lost after several ECP cycles because of contractures, skin sclerosis, or steroid effects. In this patient group with poor peripheral venous access we observed a favorable outcome by insertion of central venous catheters, either by tunneled hemodialysis catheters or by special ports.

ECP candidates with GvHD commonly present with abnormalities in their peripheral WBC count (leukopenia as well leukocytosis). To date, there is no consensus addressing the limitation of ECP in cases of leukopenia, lymphopenia, monocytopenia, or leukocytosis. Some centers do not perform ECP in cases with a very low WBC $(<1.5 \mathrm{G} / \mathrm{L})$. Specific limits are arbitrary and have not been validated. One study demonstrated that peripheral and buffy coat lymphocyte and monocyte counts strongly correlate with each other [41], suggesting that the periph- eral leukocyte count can function as a surrogate for the cell dose treated per ECP. However, taking into account the limited data, placing a WBC dependency on the decision to start ECP still needs to be left in the responsibility of the individual medical center.

GvHD patients can be affected by thrombocytopenia, either caused by GvHD itself or due to other causes. Severe thrombocytopenia $(<50 \mathrm{G} / \mathrm{L})$ can be challenging considering that patients receive anticoagulation with heparin or citrate during the ECP procedure. In our center the following scheme for ECP with heparin $(10,000 \mathrm{E})$ is standard for this patient group with a high bleeding risk: platelets $<20 \mathrm{G} / \mathrm{L}: 1$ platelet concentrate directly before the start of ECP and protamine 3,000 E directly after ECP; platelets $<50 \mathrm{G} / \mathrm{L}$ : protamine $(3,000 \mathrm{E})$ directly after ECP.

This scheme has not been scientifically evaluated so far; however, to date, we have not observed severe bleeding events in GvHD patients with this approach. Alternatively, citrate can be considered with selected devices due to its shorter half-life (see Techniques and Systems).

Besides thrombocytopenia, GvHD patients also occasionally receive long-term systemic anticoagulation due to other indications (e.g., previous venous thromboembolism and pulmonary embolism). Concomitant anticoagulation during ECP can be challenging and has to be evaluated for every patient individually based on the properties of the prescribed anticoagulant, renal function, and intake of further concomitant therapies with potential for interactions.

\section{Discussion/Conclusion}

Since the first trial on the use of ECP in CTCL was performed by Edelson et al. [4] in 1987, promising results for this therapeutic procedure in various conditions have been published. Today, ECP is an established immunomodulatory treatment in several disease entities.

Current data in GvHD is particularly encouraging, suggesting that ECP leads to no or only minor impairment of the individual immune response to pathogens and the underlying disease in comparison to other GvHD treatments. Due to the beneficial results and the favorable safety profile, ECP is continuously investigated in several experimental and clinical studies regarding the underlying pathophysiological mechanisms and clinical effects.

The current "one size fits all" strategy is rudimentary and may not be the optimal treatment approach [16]. With increasing knowledge, numerous research questions arise in ECP and require validation, i.e., How many lymphocytes and dendritic cells are required for an efficacious therapy? How much whole blood should be processed (i.e., miniECP) ? Are other blood components (e.g., platelets and coagulation factors) needed for the best efficacy? What is the 
optimal dose of 8-MOP? How long should photoactivation of cells take place? Is UVA light the best energy source for inducing the mechanisms of action? How often and in which sequence should procedures be performed for maximizing the therapy effect? Which patients would profit most from ECP treatment (personalized therapy)?

To answer these questions, further experimental research and prospective controlled multicenter trials are needed, ultimately defining the ideal role of ECP in the treatment of GvHD.

\section{Statement of Ethics}

The authors have no ethical conflicts to disclose.

\section{Disclosure Statement}

The authors have no conflict of interests to declare.

\section{Funding Sources}

The authors declare that no funding relevant to this paper exists.

\section{Author Contributions}

B.D. and A.H. reviewed and interpreted current literature and drafted, wrote, and approved this paper. A.B., L.I., G.S., and J.H. interpreted the data and revised and approved this work.

\section{References}

1 Zeiser R, Blazar BR. Acute Graft-versus-Host Disease - Biologic Process, Prevention, and Therapy. N Engl J Med. 2017 Nov;377(22): 2167-79.

2 Zeiser R, Blazar BR. Pathophysiology of Chronic Graft-versus-Host Disease and Therapeutic Targets. N Engl J Med. 2017 Dec; 377(26):2565-79.

3 Richard EG. The Science and (Lost) Art of Psoralen Plus UVA Phototherapy. Dermatol Clin. 2020 Jan;38(1):11-23.

4 Edelson R, Berger C, Gasparro F, Jegasothy B, Heald P, Wintroub B, et al. Treatment of cutaneous T-cell lymphoma by extracorporeal photochemotherapy. Preliminary results. N Engl J Med. 1987 Feb;316(6):297-303.

5 Menkes CJ, Andreu G, Heshmati F, Hilliquin P. Extracorporeal photochemotherapy. Br J Rheumatol. 1992 Nov;31(11):789-90.

6 Rook AH, Freundlich B, Jegasothy BV, Perez MI, Barr WG, Jimenez SA, et al. Treatment of systemic sclerosis with extracorporeal photochemotherapy. Results of a multicenter trial. Arch Dermatol. 1992 Mar;128(3):337-46.

7 Knobler RM. Extracorporeal photochemotherapy for the treatment of lupus erythematosus: preliminary observations. Springer Semin Immunopathol. 1994;16(2-3):323-5.

8 Owsianowski M, Gollnick H, Siegert W, Schwerdtfeger R, Orfanos CE. Successful treatment of chronic graft-versus-host disease with extracorporeal photopheresis. Bone Marrow Transplant. 1994 Nov; 14(5):845-8.

9 Knobler R, Berlin G, Calzavara-Pinton P, Greinix H, Jaksch P, Laroche L, et al. Guidelines on the use of extracorporeal photopheresis. J Eur Acad Dermatol Venereol. 2014 Jan;28 Suppl 1:1-37.

10 Padmanabhan A, Connelly-Smith L, Aqui N, Balogun RA, Klingel R, Meyer E, et al. Guidelines on the Use of Therapeutic Apheresis in Clinical Practice - EvidenceBased Approach from the Writing Committee of the American Society for Apheresis: The Eighth Special Issue. J Clin Apher. 2019 Jun;34(3):171-354.

11 Hackstein H, Amoros JJ, Bein G, Woessmann W. Successful use of miniphotopheresis for the treatment of graft-versus-host disease. Transfusion. 2014 Aug;54(8):2022-7.

12 Bladon J, Taylor PC. Extracorporeal photopheresis induces apoptosis in the lymphocytes of cutaneous T-cell lymphoma and graft-versus-host disease patients. Br J Haematol. 1999 Dec;107(4):707-11.

13 Gerber A, Bohne M, Rasch J, Struy H, Ansorge S, Gollnick H. Investigation of annexin $\mathrm{V}$ binding to lymphocytes after extracorporeal photoimmunotherapy as an early marker of apoptosis. Dermatology. 2000;201(2):111-

14 Durazzo TS, Tigelaar RE, Filler R, Hayday A, Girardi M, Edelson RL. Induction of monocyte-to-dendritic cell maturation by extracorporeal photochemotherapy: initiation via direct platelet signaling. Transfus Apheresis Sci. 2014 Jun;50(3):370-8.

15 Spisek R, Gasova Z, Bartunkova J. Maturation state of dendritic cells during the extracorporeal photopheresis and its relevance for the treatment of chronic graft-versus-host disease. Transfusion. 2006 Jan;46(1):55-65.

16 Edelson R, Wu Y, Schneiderman J. American council on ECP (ACE): why now? J Clin Apher. 2018 Aug;33(4):464-8.

17 Vowels BR, Cassin M, Boufal MH, Walsh LJ, Rook AH. Extracorporeal photochemotherapy induces the production of tumor necrosis factor-alpha by monocytes: implications for the treatment of cutaneous T-cell lymphoma and systemic sclerosis. J Invest Dermatol. 1992 May;98(5):686-92.

18 Biagi E, Di Biaso I, Leoni V, Gaipa G, Rossi V, Bugarin C, et al. Extracorporeal photochemotherapy is accompanied by increasing levels of circulating CD4+CD25+GITR+Foxp3+ CD62L+functional regulatory T-cells in patients with graft-versus-host disease. Transplantation. 2007 Jul;84(1):31-9.

19 Gatza E, Rogers CE, Clouthier SG, Lowler KP, Tawara I, Liu C, et al. Extracorporeal photopheresis reverses experimental graft-versushost disease through regulatory T cells. Blood. 2008 Aug;112(4):1515-21.

20 Hannani D. Extracorporeal photopheresis: tolerogenic or immunogenic cell death? Be- yond current dogma. Front Immunol. 2015 Jul;6:349.

21 Marshall SR. Technology insight: ECP for the treatment of GvHD-can we offer selective immune control without generalized immunosuppression? Nat Clin Pract Oncol. 2006 Jun;3(6):302-14.

22 Worel N, Mansouri Taleghani B, Strasser E. Recommendations for Therapeutic Apheresis by the Section "Preparative and Therapeutic Hemapheresis" of the German Society for Transfusion Medicine and Immunohematology. Transfus Med Hemother. 2019 Dec;46(6):394-406.

23 Pavletic SZ, Vogelsang GB, Lee SJ. 2014 National Institutes of Health Consensus Development Project on Criteria for Clinical Trials in Chronic Graft-versus-Host Disease: preface to the series. Biol Blood Marrow Transplant. 2015 Mar;21(3):387-8.

24 Jagasia MH, Greinix HT, Arora M, Williams KM, Wolff D, Cowen EW, et al. National In stitutes of Health Consensus Development Project on Criteria for Clinical Trials in Chronic Graft-versus-Host Disease: the 2014 Diagnosis and Staging Working Group report. Biol Blood Marrow Transplant. 2015; 21(3):389-401 e1.

25 Alfred A, Taylor PC, Dignan F, El-Ghariani K, Griffin J, Gennery AR, et al. The role of extracorporeal photopheresis in the management of cutaneous T-cell lymphoma, graftversus-host disease and organ transplant rejection: a consensus statement update from the UK Photopheresis Society. Br J Haematol. 2017 Apr;177(2):287-310.

26 Dignan FL, Amrolia P, Clark A, Cornish J, Jackson G, Mahendra P, et al.; Haemato-oncology Task Force of British Committee for Standards in Haematology; British Society for Blood and Marrow Transplantation. Diagnosis and management of chronic graft-versus-host disease. Br J Haematol. 2012 Jul;158(1):46-61.

27 Wolff D, Schleuning $M$, von Harsdorf S, Bacher U, Gerbitz A, Stadler M, et al. Consensus Conference on Clinical Practice in Chronic GVHD: Second-Line Treatment of Chronic Graft-versus-Host Disease. Biol Blood Marrow Transplant. 2011 Jan;17(1):1-17. 
28 Miller KB, Roberts TF, Chan G, Schenkein DP, Lawrence D, Sprague K, et al. A novel reduced intensity regimen for allogeneic hematopoietic stem cell transplantation associated with a reduced incidence of graft-versus-host disease. Bone Marrow Transplant. 2004 May; 33(9):881-9.

29 Shaughnessy PJ, Bolwell BJ, van Besien K, Mistrik M, Grigg A, Dodds A, et al. Extracorporeal photopheresis for the prevention of acute GVHD in patients undergoing standard myeloablative conditioning and allogeneic hematopoietic stem cell transplantation. Bone Marrow Transplant. 2010 Jun;45(6):1068-76.

30 Kitko CL, Braun T, Couriel DR, Choi SW Connelly J, Hoffmann S, et al. Combination Therapy for Graft-versus-Host Disease Prophylaxis with Etanercept and Extracorporeal Photopheresis: Results of a Phase II Clinical Trial. Biol Blood Marrow Transplant. 2016 May;22(5):862-8.

31 Michallet M, Sobh M, Garban F, Bulabois CE, Yakoub-Agha I, Coiteux V, et al. Extracorporeal photopheresis for GVHD prophylaxis after reduced intensity conditioning allogeneic hematopoietic stem cell transplantation: a prospective multicenter phase 2 study. Leuk Lymphoma. 2018 Feb;59(2):372-80.

32 Jagasia M, Scheid C, Socié G, Ayuk FA, Tischer J, Donato ML, et al. Randomized controlled study of ECP with methoxsalen as first-line treatment of patients with moderate to severe cGVHD. Blood Adv. 2019 Jul;3(14):2218-29.

33 Foss FM, DiVenuti GM, Chin K, Sprague K, Grodman H, Klein A, et al. Prospective study of extracorporeal photopheresis in steroidrefractory or steroid-resistant extensive chronic graft-versus-host disease: analysis of response and survival incorporating prognostic factors. Bone Marrow Transplant. 2005 Jun;35(12):1187-93.

34 Flowers ME, Apperley JF, van Besien K, Elmaagacli A, Grigg A, Reddy V, et al. A multicenter prospective phase 2 randomized study of extracorporeal photopheresis for treatment of chronic graft-versus-host disease. Blood. 2008 Oct;112(7):2667-74.

35 Greinix HT, van Besien K, Elmaagacli AH, Hillen U, Grigg A, Knobler R, et al.; UVADEX Chronic GVHD Study Group. Progressive improvement in cutaneous and extracutaneous chronic graft-versus-host disease after a 24-week course of extracorporeal photopheresis-results of a crossover randomized study. Biol Blood Marrow Transplant. 2011 Dec;17(12):1775-82.

36 Malik MI, Litzow M, Hogan W, Patnaik M, Murad MH, Prokop LJ, et al. Extracorporeal photopheresis for chronic graft-versus-host disease: a systematic review and meta-analysis. Blood Res. 2014 Jun;49(2):100-6.

37 McLeod BC, Sniecinski I, Ciavarella D, Owen $\mathrm{H}$, Price TH, Randels MJ, et al. Frequency of immediate adverse effects associated with therapeutic apheresis. Transfusion. 1999 Mar; 39(3):282-8.

38 Cloud TM, Hakim R, Griffin AC. Photosensitization of the eye with methoxsalen. II. Chronic effects. Arch Ophthalmol. 1961 Nov; 66(5):689-94

39 US Food and Drug Administration. Death and pulmonary embolism related to extracor- poreal photopheresis (ECP) treatment: letter to health care providers. 2018. Available from: https://www.fda.gov/medical-devices/lettershealth-care-providers/death-and-pulmonary-embolism-related-extracorporeal-photopheresis-ecp-treatment-letter-health-care.

40 Brosig A, Hähnel V, Orsó E, Wolff D, Holler E, Ahrens N. Technical comparison of four different extracorporeal photopheresis systems. Transfusion. 2016 Oct;56(10):2510-9.

41 Liu C, Shah K, Dynis M, Eby CS, Grossman BJ. Linear relationship between lymphocyte counts in peripheral blood and buffy coat collected during extracorporeal photopheresis. Transfusion. 2013 Nov;53(11):2635-43.

42 Zeiser R, Wolff D, Scheid C, Luft T, Greinix H, Dreger P, Finke J, Holler E. Graft-versusHost Erkrankung, akut. 2019. Available from: https://www.onkopedia.com/de/onkopedia/ guidelines/graft-versus-host-erkrankungakut/@@guideline/html/index.html.

43 Wolff D, Zeiser R, Scheid C, Luft T, Mielke S, Dreger P, Finke J, Holler E, Greinix H. Graftversus-Host Erkrankung, chronisch. 2019. Available from: https://www.onkopedia.com/ de/onkopedia/guidelines/graft-versus-hosterkrankung-chronisch/@@uideline/html/ index.html.

44 Dignan FL, Clark A, Amrolia P, Cornish J, Jackson G, Mahendra P, et al.; Haemato-oncology Task Force of British Committee for Standards in Haematology; British Society for Blood and Marrow Transplantation. Diagnosis and management of acute graft-versushost disease. Br J Haematol. 2012 Jul;158(1): 30-45.

45 Greinix HT, Worel N, Just U, Knobler R. Extracorporeal photopheresis in acute and chronic graft-versus-host disease. Transfus Apheresis Sci. 2014 Jun;50(3):349-57.

46 Greinix HT, Volc-Platzer B, Kalhs P, Fischer G, Rosenmayr A, Keil F, et al. Extracorporeal photochemotherapy in the treatment of severe steroid-refractory acute graft-versushost disease: a pilot study. Blood. 2000 Oct; 96(7):2426-31.

47 Salvaneschi L, Perotti C, Zecca M, Bernuzzi S, Viarengo G, Giorgiani G, et al. Extracorporeal photochemotherapy for treatment of acute and chronic GVHD in childhood. Transfusion. 2001 Oct;41(10):1299-305.

48 Dall'Amico R, Messina C. Extracorporeal photochemotherapy for the treatment of graft-versus-host disease. Ther Apher. 2002 Aug;6(4):296-304.

49 Messina C, Locatelli F, Lanino E, Uderzo C, Zacchello G, Cesaro S, et al. Extracorporeal photochemotherapy for paediatric patients with graft-versus-host disease after haematopoietic stem cell transplantation. Br J Haematol. 2003 Jul;122(1):118-27.

50 Greinix HT, Knobler RM, Worel N, Schneider B, Schneeberger A, Hoecker P, et al. The effect of intensified extracorporeal photochemotherapy on long-term survival in patients with severe acute graft-versus-host disease. Haematologica. 2006 Mar;91(3):405-8.

51 Greinix HT, Worel N, Knobler R. Role of extracorporeal photopheresis (ECP) in treatment of steroid-refractory acute graft-versushost disease. Biol Blood Marrow Transplant. 2010 Dec;16(12):1747-8.
52 Garban F, Drillat P, Makowski C, Jacob MC, Richard MJ, Favrot M, et al. Extracorporeal chemophototherapy for the treatment of graft-versus-host disease: hematologic consequences of short-term, intensive courses. Haematologica. 2005 Aug;90(8): 1096-101.

53 Kanold J, Merlin E, Halle P, Paillard C, Marabelle A, Rapatel C, et al. Photopheresis in pediatric graft-versus-host disease after allogeneic marrow transplantation: clinical practice guidelines based on field experience and review of the literature. Transfusion. $2007 \mathrm{Dec}$; 47(12):2276-89.

54 Calore E, Calò A, Tridello G, Cesaro S, Pillon M, Varotto S, et al. Extracorporeal photochemotherapy may improve outcome in children with acute GVHD. Bone Marrow Transplant. 2008 Sep;42(6):421-5.

55 Perfetti P, Carlier P, Strada P, Gualandi F, Occhini D, Van Lint MT, et al. Extracorporeal photopheresis for the treatment of steroid refractory acute GVHD. Bone Marrow Transplant. 2008 Nov;42(9):609-17.

56 González-Vicent M, Ramírez M, Pérez A, Lassaletta A, Sevilla J, Díaz MA. Extracorporeal photochemotherapy for steroid-refractory graft-versus-host disease in low-weight pediatric patients. Immunomodulatory effects and clinical outcome. Haematologica. 2008 Aug;93(8):1278-80.

57 Perotti C, Del Fante C, Tinelli C, Viarengo G, Scudeller L, Zecca M, et al. Extracorporeal photochemotherapy in graft-versushost disease: a longitudinal study on factors influencing the response and survival in pediatric patients. Transfusion. 2010 Jun; 50(6):1359-69.

58 Malagola M, Cancelli V, Skert C, Leali PF, Ferrari E, Tiburzi A, et al. Extracorporeal Photopheresis for Treatment of Acute and Chronic Graft Versus Host Disease: An Italian Multicentric Retrospective Analysis on 94 Patients on Behalf of the Gruppo Italiano Trapianto di Midollo Osseo. Transplantation. 2016 Dec;100(12):e147-55.

59 Niittyvuopio R, Juvonen E, Heiskanen J, Lindström V, Nihtinen A, Sahlstedt L, et al. Extracorporeal photopheresis in the treatment of acute graft-versus-host disease: a single-center experience. Transfusion. 2018 Aug;58(8):1973-9.

60 Cid J, Carbassé G, Suárez-Lledó M, Moreno DF, Martínez C, Gutiérrez-García G, et al. Efficacy and safety of one-day offline extracorporeal photopheresis schedule processing one total blood volume for treating patients with graft-versus-host disease. Transfusion. 2019 Aug;59(8):2636-42.

61 Greinix HT, Volc-Platzer B, Rabitsch W, Gmeinhart B, Guevara-Pineda C, Kalhs P, et al. Successful use of extracorporeal photochemotherapy in the treatment of severe acute and chronic graft-versus-host disease. Blood. 1998 Nov;92(9):3098-104.

62 Seaton ED, Szydlo RM, Kanfer E, Apperley JF, Russell-Jones R. Influence of extracorporeal photopheresis on clinical and laboratory parameters in chronic graft-versushost disease and analysis of predictors of response. Blood. 2003 Aug; 102(4):121723. 
63 Apisarnthanarax N, Donato M, Körbling M, Couriel D, Gajewski J, Giralt S, et al. Extracorporeal photopheresis therapy in the management of steroid-refractory or steroid-dependent cutaneous chronic graft-versus-host disease after allogeneic stem cell transplantation: feasibility and results. Bone Marrow Transplant. 2003 Mar;31(6):459-65.

64 Rubegni P, Cuccia A, Sbano P, Cevenini G, Carcagnì MR, D'Ascenzo G, et al. Role of extracorporeal photochemotherapy in patients with refractory chronic graft-versus-host disease. Br J Haematol. 2005 Jul;130(2):271-5.

65 Greinix HT, Socié G, Bacigalupo A, Holler E, Edinger MG, Apperley JF, et al. Assessing the potential role of photopheresis in hematopoietic stem cell transplant. Bone Marrow Transplant. 2006 Aug;38(4):265-73.
66 Couriel DR, Hosing C, Saliba R, Shpall EJ, Anderlini P, Rhodes B, et al. Extracorporeal photochemotherapy for the treatment of steroidresistant chronic GVHD. Blood. 2006 Apr; 107(8):3074-80.

67 Perseghin P, Dassi M, Balduzzi A, Rovelli A, Bonanomi S, Uderzo C. Mononuclear cell collection in patients undergoing extra-corporeal photo-chemotherapy for acute and chronic graft-vs.-host-disease (GvHD): comparison between COBE Spectra version 4.7 and 6.0 (AutoPBSC). J Clin Apher. 2002; 17(2):65-71.

68 Dignan FL, Greenblatt D, Cox M, Cavenagh J, Oakervee H, Apperley JF, et al. Efficacy of bimonthly extracorporeal photopheresis in refractory chronic mucocutaneous GVHD. Bone Marrow Transplant. 2012 Jun;47(6): 824-30.
69 Del Fante C, Scudeller L, Viarengo G, Bernasconi P, Perotti C. Response and survival of patients with chronic graft-versus-host disease treated by extracorporeal photochemotherapy: a retrospective study according to classical and National Institutes of Health classifications. Transfusion. 2012 Sep;52(9): 2007-15.

70 Hautmann AH, Wolff D, Hahn J, Edinger M, Schirmer N, Ammer J, et al. Extracorporeal photopheresis in 62 patients with acute and chronic GVHD: results of treatment with the COBE Spectra System. Bone Marrow Transplant. 2013 Mar;48(3):439-45. 